\title{
KOMPOSISI POHON DI BUKIT ACE KELURAHAN GUNUNG SARIK KECAMATAN KURANJI PADANG
}

\author{
Rizki dan Elza Safitri \\ Program Studi Pendidikan Biologi STKIP PGRI Sumatera Barat. \\ Jalan. Gunung Pangilun Padang. \\ Email: khi_bio@yahoo.com
}

\begin{abstract}
The existence of trees in a region could be threatened because of their good forest damage due to natural factors such as fires and landslides, as well as human activities mainly due to illegal logging. This study aims to determine the composition of a tree in Bukit Ace in the sub Kuranji Padang. In this study using a survey method using a combination of methods to make trransek track and map examples. Transects were observed along the 20 meter by 10 mapped sample with a size of 10x10 meter Analysis of vegetation cover density, frequency, dominance, importance and diversity index. Based on research conducted at the Mount Ace Village of Mount Sarik District of Kuranji Padang, tree composition consists of 13 species and 172 individuals where species of trees by people who at least is Anacardium ocidentale ie 3 people whereas species with people most is Xerospermum intermedium (31 people), Important values ranging between $6.107 \%-60.327 \%$, of tree species that have significant value the highest is Xerospermum intermedium is $60.327 \%$ and tree species with important value lows are Evodia malayana namely $6.107 \%$, while based on diversity index of forest in Bukit Ace classified as being abundant with value ID 2,351.
\end{abstract}

Keywords: tree, hill ace, composition, analysis vegetation

\section{PENDAHULUAN}

Hutan tropika Indonesia menyimpan berbagai species flora dan fauna yang menjadikan Indonesia sebagai salah satu sumber megabiodivesiti dunia. Berbagai jenis tumbuhan dan hewan menyusun lantai hutan yang terbentang dari utara pulau Sumatera sampai ujung timur Papua. Satu diantara penyusun hutan tersebut adalah pohon, jumlah species pohon penyusun hutan ini belum diketahui secara pasti, namun diperkirakan oleh alhi botani bahwa jumlahnya lebih dari 40.000 species dan $10 \%$ diantaranya adalah species pohon. Dengan jumlah tersebut dapat dikatakan bahwa jumlah jenis pohon yang ada di Indonesia itu bukanlah jumlah yang sedikit, oleh karena itu diperlukan pengenalan species pohon untuk menjaga kekayaan alam Indonesia (Partomihardjo et al, 2014).

Pohon merupakan tumbuhan berkayu (aboceus perineal) dengan masa hidup lebih dari dua tahun yang biasanya memiliki batang pokok dengan tinggi lebih dari enam meter (Ridsdale, 2005). Pohon merupakan salah satu penyusun tegakan hutan selain sapling, seedling, dan tumbuhan penutup tanah (ground cover) yang membentuk kanopi sebagai bentuk penguasan terhadap lahan yang ditumbuhinya.

Kerusakan ekosistem dapat menurunkan kualitas hutan. Hal ini dapat terjadi karena faktor alami dan faktor kegiatan manusia. Faktor alami yang dapat merusak ekosistem 
seperti banjir, tanah longsor, tsunami dan gunung meletus. Faktor manusia yang dapat menyebabkan kerusakan ekosistem misalnya kegiatan pembakaran hutan, ladang berpindah, perburuan, penebangan hutan, peledakan terumbu karang, beberapa kegiatan pertanian, industrialisasi dan eksploitasi sumber daya alam yang berlebihan (Mardiastutik, 2010).

Salah satu kegiatan yang dapat menyebabkan kerusakan hutan saai ini adalah pembalakan liar dan pembakaran hutan. Pembalakan liar atau ilegal logging adalah penebangan, pengangkutan dan penjualan kayu yang tidak sah atau tidak memiliki izin dari otoritas setempat. Sebagian besar kerusakan hutan di Indonesia akibat dari sistem politik dan ekonomi yang menganggap sumber daya hutan sebagai sumber pendapatan dan bisa di eksploitasi untuk kepentingan politik serta keuntungan pribadi (Indriyanto, 2010). Bukit Ace terletak di Kelurahan Gunung Sarik, Kecamatan Kuranji Padang. Bukit ini ini termasuk salah satu hutan lindung di kota Padang, namun 02 Agustus 2011 telah terjadi kebakaran lahan di hutan ini yang menyebabkan kerusakan cukup parah, namun kebakaran ini tidak menyebabkan semua pohon terbakar, sebagian pohon masih mampu bertahan hidup dan bertunas kembali, selain itu pembalakan liar juga memperparah kondisi hutan di Bukit Ace Padang ini.

\section{METODE PENELITIAN}

Penelitian dilakukan selama empat bulan di Bukit Ace Kelurahan Gunung Sarik, Kecamatan Kuranji, Padang. Bahan penelitian ini ialah berupa sampel tumbuhan, alkohol 96\%, tali rafia, pancang kayu label herbarim, sedangkan alat yang digunakan adalah Meteran 50 meter, meteran kain (dikalibrasi), Kompas, Thermometer, Hygrometer, Alat tulis, Kamera digital, busur, pisau cutter, parang dan modifikasi stick meter. Penelitian ini dilakukan dengan kombinasi metode jalur dan garis berpetak dengan cara membuat jalur dengan menggunakan kompas tegak lurus sepanjang perbukitan. Kemudian ditarik transek dari titik pertama dengan menggunakan tali rafia yang diikatkan pada pancang kayu dengan jarak pancang pertama dan pancang selanjutnya adalah 10 meter (plot 1) dan dibuat sebanyak 20 plot. Kemudian dicatat species pohon yang dapat dalam transek tersebut dan dihitung berapa jumlahnya. Pengamatan dilakukan pada tumbuhan dengan diameter batang $\geq 10 \mathrm{~cm}$.

Pengukuran paramter ekologi yang menggambarkan komposisi pohon meliputi kerapatan, frekwensi, dominansi, indeks nilai penting pada masing-masing pohon, indeks diversitas dan indeks similaritas (Odum, 1993).

Analisis data dilakukan dengan rumus sebagai berikut: Kerapatan (K) (Odum, 1993): $\mathrm{K}=\frac{\text { Jumlah individu suatu species (i) }}{\text { Luas plot }}$; Kerapatan Relatif $(\mathrm{KR})=\frac{\text { Kerapatan suatu species (i) }}{\text { Kerapatan seluruh species }} \mathrm{x}$ 100\%; Frekuensi $\quad(\mathrm{F}) \quad=$ $\frac{\text { Jumlah plot ditemukannya species (i) }}{\text { Total seluruh plot }}$ Frekuensi Relatif $(\mathrm{FR})=\frac{\text { Frekuensi suatu species (i) }}{\text { Frekuensi seluruh species }} \mathrm{X}$ 100\%; Dominansi $\quad$ (D) = $\frac{\text { Jumlah luas bidang dasar species (i) }}{\text { Luas plot }} \quad$ Dominansi Relatif $(\mathrm{DR})=\frac{\text { Dominansi suatu species (i) }}{\text { dominansi seluruh species }} \mathrm{x}$ $100 \%$;

Indeks Nilai Penting (INP) atau Importance Value Index (IVI) digunakan untuk meranking spesies berdasarkan kepentingan ekologinya. Dan INP adalah jumlah kerapatan relatif (KR), Dominansi relatif (DR) dan frekuensi relatif (FR). Untuk menghitung Indeks Nilai Penting digunakan rumus berikut : INP $=$ Kerapatan Relatif $(\%)+$ Frekuensi relatif $(\%)+$ Dominansi Relatif (\%)

Indeks diversitas dapat diukur dengan rumus Shannon - Wiener sebagai berikut (Stilling, 2012) : $\mathrm{H}^{\prime}=-\sum \mathrm{Pi} \ln \mathrm{Pi}$, dengan $\mathrm{H}^{\prime}=$ Indeks diversitas Shannon - Wiener; $\mathrm{Pi}=\mathrm{ni} / \mathrm{N}$; $\mathrm{ni}=$ Jumlah individu dari suatu species; $\mathrm{N}=$ 
Jumlah total individu seluruh species; Besarnya indeks diversitas suatu species menurut Shannon- Wiener didefinisikan sebagai berikut (Fachrul, 2007). Nilai $\mathrm{H}^{\prime}>3$ menunjukkan bahwa keanekaragaman species pada suatu transek adalah melimpah tinggi; Nilai $\mathrm{H}^{\prime}$ $1 \leq \mathrm{H}^{\prime} \leq 3$ menunjukkan bahwa keanekaragaman species pada suatu transek adalah sedang melimpah dan Nilai $\mathrm{H}^{\prime}<1$ menunjukkan bahwa keanekaragaman species pada suatu transek adalah sedikit atau rendah.

\section{HASIL DAN PEMAHASAN}

Berdasarkan penelitian yang telah dilakukan di Bukit Ace Kelurahan Gunung Sarik Kecamatan Kuranji Padang, komposisi pohon terdiri dari 13 species dan 172 individu. Uraian komposisi pohon secara rinci dapat dilihat pada Tabel 1 .

Table 1. Komposisi pohon di Bukit Ace Kelurahan Gunung Sarik Kecamatan Kuranji Padang

\begin{tabular}{cllc}
\hline No & \multicolumn{1}{c}{ Familia } & \multicolumn{1}{c}{ Nama Species } & Jumlah Individu \\
\hline 1 & Anacardiaceae & Anacardium occidantale & 3 \\
2 & Apocynaceae & Alastonia scholaris & 25 \\
3 & Moraceae & Artocarpus elasticus & 13 \\
4 & Melastomataceae & Bellucia pentamera & 5 \\
5 & Rutaceae & Evodia malayana & 4 \\
6 & Clusiaceae & Garcinia sp. & 4 \\
7 & Ixonantaceae & Ixonathes sp. & 16 \\
8 & Verbenaceae & Perenoma canescens & 8 \\
9 & Lauraceae & Phoebe sp & 24 \\
10 & Myrtaceae & Rhodamnia cinerea & 17 \\
11 & Symplocaceae & Symplocos fasciculata & 12 \\
12 & Vitaceae & Vitex pinata & 10 \\
13 & Sapindaceae & Xerospermum intermedium & 31 \\
\hline & & & 172 \\
\hline
\end{tabular}

Hasil perhitungan kerapatan, kerapatan dan indeks keanekaragaman di Bukit Ace relative, frekuensi, frekuensi relative, Kelurahan Gunung Sarik Kecamatan Kuranji dominansi, dominansi relative, nilai penting, Padang terlihat pada Tabel 2.

Tabel 2. Nilai perhitungan kerapatan, kerapatan relatif, frekuensi, frekuensi relatif, dominansi, dominansi relatif, nilai penting, dan indeks keanekaragaman 13 species yang terdapat di Bukit Ace Kelurahan Gunung Sarik Kecamatan Kuranji Padang. 
Rizki., \& Safitri., E. 2016. Komposisi Pohon di Bukit Ace Kelurahan Gunung Sarik Kecamatan Kuranji Padang. Journal of Sainstek 8(2): 142-149

\begin{tabular}{llllllllll}
\hline No & \multicolumn{1}{c}{ Species } & $\mathrm{K}$ & $\mathrm{KR}$ & $\mathrm{F}$ & $\mathrm{FR}$ & $\mathrm{D}$ & $\mathrm{DR}$ & $\mathrm{INP}$ & $\mathrm{Pi}$ Ln Pi \\
& & & & & & & & \\
\hline 1 & $\begin{array}{l}\text { Anacardium } \\
\text { occidantale }\end{array}$ & 0.0015 & 1.744 & 0.15 & 2.970 & 0.566 & 1.486 & 6.201 & -0.071 \\
2 & Alastonia scholaris & 0.0125 & 14.535 & 0.65 & 12.871 & 6.539 & 17.173 & 44.579 & -0.280 \\
3 & Artocarpus elasticus & 0.0065 & 7.558 & 0.35 & 6.931 & 3.484 & 9.149 & 23.638 & -0.195 \\
4 & Bellucia pentamera & 0.0025 & 2.907 & 0.2 & 3.960 & 0.531 & 1.394 & 8.262 & -0.103 \\
5 & Evodia malayana & 0.002 & 2.326 & 0.15 & 2.970 & 0.309 & 0.811 & 6.107 & -0.087 \\
6 & Garcinia sp. & 0.002 & 2.326 & 0.15 & 2.970 & 0.332 & 0.873 & 6.169 & -0.087 \\
7 & Ixonathes sp. & 0.008 & 9.302 & 0.45 & 8.911 & 4.285 & 11.253 & 29.466 & -0.221 \\
8 & Perenoma canescens & 0.004 & 4.651 & 0.35 & 6.931 & 1.574 & 4.134 & 15.716 & -0.143 \\
9 & Phoebe sp & 0.012 & 13.953 & 0.65 & 12.871 & 4.889 & 12.839 & 39.664 & -0.275 \\
10 & Rhodamnia cinera & 0.0085 & 9.884 & 0.5 & 9.901 & 2.900 & 7.617 & 27.402 & -0.229 \\
11 & Symplocos fasciculate & 0.006 & 6.977 & 0.35 & 6.931 & 1.623 & 4.262 & 18.170 & -0.186 \\
12 & Vitex piñata & 0.005 & 5.814 & 0.3 & 5.941 & 0.970 & 2.546 & 14.301 & -0.165 \\
13 & $\begin{array}{l}\text { Xerospermum } \\
\text { intermedium }\end{array}$ & 0.0155 & 18.023 & 0.8 & 15.842 & 10.076 & 26.462 & 60.327 & -0.309 \\
& & & & & & & $-\sum \mathrm{Pi}$ & 2.351 \\
\hline & & & & & & & $1 n \mathrm{Pi}=$ & \\
\hline
\end{tabular}

Tabel 3. Hasil Faktor Lingkungan

\begin{tabular}{cll}
\hline No & \multicolumn{1}{c}{ Pengukuran Faktor Lingkungan } & \multicolumn{1}{c}{ Hasil } \\
\hline 1 & Kelembapan (\%) & $55 \%-71 \%$ \\
2 & Suhu ( $\left.{ }^{\circ} \mathrm{C}\right)$ & $31-33^{\circ} \mathrm{C}$ \\
3 & pH tanah & $6,9-7$ \\
\hline
\end{tabular}

Jumlah individu pohon di Bukit Ace Kelurahan Gunung Sarik Kecamatan Kuranji Padang, dari penelitian yang dilakukan didapatkan 172 individu dalam plot pengamatan $2000 \mathrm{~m}^{2}$. Jika dibandingkan dengan hasil penelitian Okvia (2008) di Hutan Batu Busuk Kelurahan Lambung Bukit Kecamatan Pauh Padang didapatkan 152 individu dengan areal penelitian seluas $2400 \mathrm{~m}^{2}$, Salah satu faktor yang menyebabkan perbedaan jumlah individu pada masing-masing tempat yaitu dari faktor lingkungan pada masing-masing lokasi. Seperti halnya menurut Ewusie (1990) kepadatan populasi suatu jenis organisme di suatu tempat mungkin berbeda dengan tempat lain dan kepadatan sekarang berbeda dengan masa dulu dan yang datang, perbedaan kepadatan populasi itu di karenakan berbedanya faktor lingkungan antara suhu daerah dengan daerah lainya, sepanjang perjalanan waktu. Dengan demikian kepadatan populasi suatu jenis organisme boleh dikatakan tidak pernah tetap. Bagi tumbuhan keadaan tanah, habitat dan iklim sangat menentukan pertumbuhan tumbuhan tersebut.

Hasil kerapatan relative berkisar antara 1,174 \%-18,023\%, dari Tabel 2 dapat dilihat species pohon yang mempunyai nilai kerapatan relative tertinggi adalah Xerospermum intermedium yaitu $18,023 \%$, Sedangkan species dengan nilai kerapatan relative terendah adalah Anacardium ocidentale yaitu $1,744 \%$, salah satu faktor yang turut mempengaruhinya yaitu adanya faktor kemampuan regenerasi yang tinggi dan dipengaruhi oleh keadaan lingkungan. Pada dasarnya vegetasi yang ditemukan di hutan seperti di atas adalah 
vegetasi hutan sekunder, yang umumnya merupakan kawasan hutan dengan tajuk pohon yang agak terbuka karena pernah mengalami gangguan secara fisik karena kebakaran, longsor dan penebangan beberapa individu. Selain itu kehadiran suatu species pohon pada suatu vegetasi merupakan petunjuk bahwa secara alami species tumbuhan cocok dengan kondisi lingkungan vegetasi tersebut

Nilai frekuensi relative berkisar antara $2,970 \%-15,842 \%$, species pohon yang memiliki nilai frekuensi tertinggi adalah Xerospermum intermedium yaitu $15,842 \%$, sedangkan nilai frekuensi relative terendah adalah Anacardium occidantale, Evodia malayana, dan Garcinia sp., yaitu $2,970 \%$. Tingginya frekuensi relative karena kehadiran jenis ini tergantung pada kondisi habitat dan lingkungan yang cocok dengan tumbuhan tersebut. Disamping keunggulan di dalam berkompetisi terhadap ruang, unsur hara dan cahaya matahari yang diperlukan di dalam pertumbuhan dan perkembangannya (Moenandir, 1998). Kemudian rendahnya nilai frekuensi relative hal ini berarti kawasan hutan di Bukit Ace Kelurahan Gunung Sarik tergolong sudah terganggu. Menurut Fachrul (2007), nilai kerapatan relatif dapat menggambarkan pola penyesuaian bagi suatu species, apabila nilai kerapatan relatif tinggi maka species tersebut memiliki pola penyesuaian yang besar, sedangkan apabila sebaliknya maka species tersebut memiliki pola penyesuaian yang kecil.

Dominansi relative berkisar antara 0,811\%-26,462\%, species pohon yang memiliki dominansi relative tertinggi adalah Xerospermum intermedium yaitu $26,462 \%$, dan species pohon yang memiliki nilai dominansi terendah adalah Evodia malayana yaitu $0,811 \%$. Tingginya nilai dominansi relative berarti species pohon tersebut memiliki ratarata diameter yang besar sehingga penguasaan daerahnya lebih luas dibandingkan dengan species yang lain. Nilai dominansi relative suatu jenis vegetasi dapat memberikan gambaran bagaimana tingkat penguasaan suatu daerah oleh setiap species tumbuhan. Menurut Arrijani (2008) jenis yang mendominasi suatu areal dinyatakan sebagai jenis yang memiliki kemampuan adaptasi dan toleransi yang lebar terhadap kondisi lingkungan. Kemudian rendahnya nilai dominansi relative disebabkan species tersebut tidak mampu beradaptasi dengan lingkunganya serta kalah bersaing dengan yang lain. Menurut Maisyaroh (2010) adanya species yang mendominansi dapat dipengaruhi oleh beberapa faktor antara lain adalah persaingan antara tumbuhan yang ada, dalam hal ini berkaitan dengan iklim dan mineral yang diperlukan, jika iklim dan mineral yang dibutuhkan mendukung maka species tersebut akan lebih unggul dan lebih banyak ditemukan.

Nilai Penting (NP) berkisar antara 6,107\%-60,327\%, species pohon yang memiliki nilai penting tertinggi adalah Xerospermum intermedium yaitu 60,327\%. Sedangkan species pohon dengan nilai penting terendah adalah Evodia malayana yaitu $6,107 \%$. Nilai penting suatu jenis memberikan gambaran bahwa keberadaan jenis tersebut semakin stabil atau berpeluang untuk dapat mempertahankan pertumbuhan dan kelestarian jenisnya. Menurut Fachrul (2007) bahwa tingginya NP pada suatu species tersebut menggambarkan pentingnya peranan suatu species dalam ekosistemnya dan mempengaruhi kestabilan ekosistem tersebut. Species tumbuhan yang mempunyai nilai penting tertinggi diantara vegetasi sesamanya menunjukan bahwa tingkat penguasaanya dalam komunitas paling besar atau dominan. Kemudian Menurut Ferianita (2006) suatu jenis tingkat pohon dan tingkat tiang dapat dikatakan berperan jika NP $\geq 15 \%$, sedangkan pada tingkat pancang dan semai dikatakan berperan jika memiliki NP $\geq 10 \%$.

Nilai Indeks Diversitas (Keanekaragaman) species pohon di Bukit Ace Kelurahan Gunung Sarik Kecamatan Kuranji Padang tergolong sedang melimpah, dimana nilai indeks keanekaragaman 2,351. Menurut Fachrul (2007) Besarnya indeks diversitas suatu 
species menurut Shannon-Wiener didefinisikan nilai $\mathrm{H}^{\prime}>3$ menunjukkan bahwa keanekaragaman species pada suatu transek adalah melimpah tinggi, nilai $\mathrm{H}^{\prime} 1 \leq \mathrm{H}^{\prime} \leq 3$ menunjukkan bahwa keanekaragaman species pada suatu transek adalah sedang melimpah dan nilai $\mathrm{H}^{\prime}<1$ menunjukkan bahwa keanekaragaman species pada suatu transek adalah sedikit atau rendah. Melalui indeks keragaman, indeks keseragaman, dan indeks dominansi dapat diketahui bahwa perubahan tersebut terjadi karena hutan sedang beregenerasi setelah mengalami gangguan (Handayani, 2015). Penurunan keanekaragaman vegetasi ini juga dapat diakibatkan oleh kebakaran. Kebakaran hutan juga pernah terjadi di kawasan hutan wisata Rimbo Tujuh Danau yang menyebabkan penurunan jumlah jenis pada tingkat pohon dan menurunkan nilai kerapatan serta berpengaruh terhadap vegetasi yang tumbuh setelah kebakaran dan meningkatkan keasaman tanah yang memperparah keadaan hutan di daerah ini. (Esti, 2011); Kardiman (2011) pembalakan liar juga terjadi Bukit Gajabuih setelah 14 tahun penebangan liar di bukit ini merubah komposisi dan tegakan pohon. Setelah penebangan ditemukan hampir setengah dari komposisi tegakan pohon sebelum penebangan kawasan hutan plot permanen bukit Gajabuih mengalami penurunan.

Keadaan lingkungan di Bukit Ace Kelurahan Gunung Sarik Kecamatan Kuranji Padang suhu berkisar antara $31{ }^{\circ} \mathrm{C}$ sampai dengan $33{ }^{\circ} \mathrm{C}$. Kelembaban berkisar $55 \%$ sampai dengan $71 \%$, pH tanah di bukit ini berkisar antara 6,9 sampai 7 bersifat asam. Ewusie (1990) hutan hujan tropis memiliki kelembaban $80 \%$ dengan suhu $\left(25-26^{\circ} \mathrm{C}\right)$. Dapat di lihat bahwa faktor lingkungan dibukit Ace berpengaruh terhadap keanekaragaman pohon. Apabila suhu melampaui batas maksimum dan minimum maka pertumbuhan dan perkembangan akan terhenti. Berdasarkan hasil pengukuran parameter lingkungan di Bukit Ace kelurahan Gunung Sarik Kecamatan
Kuranji Padang suhu relatif tinggi. namun tumbuhan memiliki kondisi optimum untuk tumbuh yang berbeda-beda. Pada lokasi penelitian tersebut banyak celah akibat penebangan yang memungkinkan cahaya matahari masuk lebih banyak ke lantai hutan. Banyaknya celah ini menyebabkan tingginya suhu udara dan rendahnya kelembaban udara di lokasi ini.

Pada area penelitian diameter batang yang besar dari $35 \mathrm{~cm}$ atau pohon dewasa hanya sedikit di temukan di area penelitian. Pohon dewasa adalah pohon masa lampau yang pernah ada diarea penelitian. Akibat kebakaran hutan dan pembalakan liar di bukit Ace maka pohon yang ditemukan merupakan sisa dari kebakaran dan pembalakan. Pohon yang mempunyai diameter 10-35 atau pohon muda (Pole) banyak ditemukan pada area penelitian. Pohon muda merupakan pohon masa sekarang. Pada bukit Ace kelurahan Gunung Sarik kecamatan Kuranji Padang, banyak tumbuhan muda yang tersebar di area penelitian yang mempunyai diameter batang kurang dari $10 \mathrm{~cm}$. Pohon yang memiliki diameter kurang dari 10 $\mathrm{cm}$ merupakan tingkat sapling (belta). Pohon ini nantinya akan menjadi menjadi pohon muda dan pohon inti atau pohon masa depan jika ekosistem di bukit tersebut tidak rusak dan masyarakat sadar dan peduli terhadap keadaan bukit Ace. Jika masyarakat masih kurang peduli terhadap kelestarian bukit ini pada masa akan datang pohon di bukit ini akan mengalami penurunan jumlah.

\section{KESIMPULAN}

Penelitian yang telah dilakukan di Bukit Ace Kelurahan Gunung Sarik Kecamatan Kuranji Padang, diketahui bahwa komposisi pohon terdiri dari 13 species dan 172 individu dimana species pohon dengan individu yang paling sedikit ialah Anacardium ocidentale yaitu 3 individu sedangkan species dengan individu terbanyak adalah Xerospermum intermedium (31 individu). Nilai penting 
berkisar antara 6,107\% - 60,327\%, species pohon yang memiliki nilai penting tertinggi adalah Xerospermum intermedium yaitu $60,327 \%$ dan species pohon dengan nilai penting terendah adalah Evodia malayana yaitu $6,107 \%$. Sedangkan berdasarkan Indeks Diversitas hutan di Bukit Ace tergolong sedang berlimpah dengan nilai ID 2,351

\section{UCAPAN TERIMAKASIH}

Terimakasih kami ucapkan kepada rekanrekan tim penelitian: Nosmi Firmasari, Wiwin Lenasari, Hikmah Pertiwi dan semua pihak yang telah yang telah membantu dalam penyelesaian penelitian ini

\section{DAFTAR KEPUSTAKAAN}

Arrijani A. 2008. Vegetation structure and composition of the montane zone of Mount Gede Pangrango National Park. Biodiversitas, Journal of Biological Diversity, $\quad 9(2), \quad$ 134-141. http://doi.org/10.13057/biodiv/d090212.

Bayu LCP, Togar FM \& Wahdina. 2015. Keanekaragaman Jenis Vegetasi Pohon Hutan Adat Gunung Semarong Di Desa Mandong Kecamatan Tayan Hulu Kabupaten Sanggau. Jurnal. Fakultas Kehutanan Universitas Tanjung Pura.

Dendang D dan Handayani W. 2015. Struktur dan komposisi tegakan hutan di Taman Nasional Gunung Gede Pangrango, Jawa Barat. Jurnal PROS SEM NAS MASY BIODIV INDON. N0 4. Vol 1. Hal 691695.

Esti K. 2011. Komposisi dan Struktur vegetasi Pada Areal Hutan Bekas Terbakar (Di Areal UPT Taman Hutan Raya R. Soerjo, Malang). Disertation Abstract International. E44062865.

Ewusie JY. 1990. Pengantar Ekologi Tropika. Penerjemah Usman Tanuwijaya. Bandung. Penerbit ITB.
Ferianita M. 2006. Metode Sampling Bioekologi. Jakarta: Bumi Aksara.

Firmasari N. 2015. Stratifikasi pohon di Bukit Ace Kelurahan Gunung Sarik Kecamatan Kuranji Padang. Skripsi. Padang: STKIP PGRI Sumatera Barat.

Fachrul FM. 2007. Metode Sampling Bioekologi. Jakarta: Bumi Aksara.

Gumiati IA. 2015. Komposisi Nimfa Odonata di Batang Tambangan Kenagarian Tambangan Kecamatan X Koto Kabupaten Tanah Datar. Skripsi. Padang: STKIP PGRI.

Indriyanto. 2006. Ekologi Hutan. Jakarta: Bumi Aksara.

Indriyanto. 2010. Pengantar Budidaya Hutan. Jakarta: Bumi Aksara.

Kardiman. 2011. Struktur Tegakan Pohon Setelah 14 Tahun Penebangan di Plot Permanen Bukit Gajabuih. Unand. Padang.

Maisyaroh W. 2010. Struktur Komunitas Tumbuhan Penutup Tanah di Taman Hutan Raya R . Soerjo Cangar, Malang Structure of Ground Cover Plant Community R . Soerjo Grand Forest Malang. Pembangunan Dan ALam Lestari, 1(1), 1-9.

Mardiastutik DE. 2010. Mengenal Ekosistem. Jakarta: Mitra Utama.

Odum EP. 1993. Dasar-Dasar Ekologi. Edisi ke III. Terjemahan Tjahjono Samingan. Yogyakarta: Penerbit Gadjah Mada Press.

Okvia Y. 2008. Komposisi vegetasi pohon di hutan batu busuak Kelurahan Lambuang Bukit Kecamatan Pauh Kota Padang. Skripsi. Padang: STKIP PGRI Padang.

Partomihardjo T, D Arifiani, BA Pratama, R Mahyuni. 014. Jenis-Jenis Pohon Penting di Hutan Nusakambangan. Jakarta: LIPI Press. 
Rizki., \& Safitri., E. 2016. Komposisi Pohon di Bukit Ace Kelurahan Gunung Sarik Kecamatan Kuranji Padang. Journal of Sainstek 8(2): 142-149

Purborini DH. 2006. Struktur dan Komposisi Tumbuhan Di Kawasan Rawa Pening Kabupaten Semarang Jawa Tengah. Skripsi. Semarang: UNS.

Ridsdale C, J White, Carol Ushes. 2005. Trees (Identification, Forest, Historic Species, Wood Types. London: Dorling Kindersley Limited.
Setiadi D. 2005. Keanekaragaman spesies tingkat pohon di taman wisata alam Ruteng, Nusa Tenggara Timur. Biodiversitas 6 (2): 118-122.

Stilling P. 2012. Ecology: Global Insights Investigation. McGraw-Hill Education. United States of America. 